\title{
Descentrar la educación e investigación: una urgencia en tiempos de pandemia
}

\author{
Jorge Luis Yangali Vargas \\ Universidad Nacional del Centro del Perú \\ jyangali@uncp.edu.pe \\ https://orcid.org/oooo-0003-3714-326X \\ https://doi.org/10.26490/uncp.horizonteciencia.2020.19.583
}

Durante esta etapa de confinamiento los sistemas educativos nacionales vienen implementando estrategias para aprender en modo remoto. En el Perú, el Ministerio de Educación tuvo que reconocer el grave error de invalidar en su sistema universitario la educación a distancia (véase la modificación del artículo 47 de la Ley 30220 en el Decreto Legislativo 1496). Motivo por el cual las universidades, en especial las públicas, están aprendiendo en el terreno a conducir el proceso educativo desde lo virtual.

En la Educación Básica Regular se ha implementado el programa de formación a distancia "Aprendo en casa" (Minedu 2020), el cual es dirigido por los docentes con el soporte tecnológico de la televisión y radio nacional. Durante los últimos años; en razón a la desmonopolización del servicio telefónico celular varias operadoras han alentado, en la población en general, la adquisición de equipos con servicio de internet incluido. Esta "previsión comunitaria”, de algún modo, hoy viene facilitando la interacción entre docentes y estudiantes a través del uso de aplicativos de vídeo y mensajes de texto.

No obstante, la calidad en cuanto a tecnología, interacción y virtualidad no es la misma para todas las personas y para todas las regiones; siguiendo a Sebastián Plá (2017) podemos afirmar que esta no garantiza la equidad y la igualdad en el acceso a la educación como bien común. En países de larga tradición centralista, como el Perú, la calidad tiene como principal unidad de medida la proximidad al centro, a la capital y a los productos culturales que se gestan entre los administradores del poder. La desatención de servicios básicos para el aprendizaje virtual, tiene la misma lógica que la desatención en salud, aludimos a la pandemia actual: señal de internet ralentizada en zonas rurales, más aún en la Amazonía peruana; precariedad en los equipos para aprender "en vivo" o mediante video; contenidos (televisivos y radiales), producidos en y desde Lima; etc.

Las regiones, pese contar con equipos y personal capacitado, se ve limitado en sus facultades resolutivas, por ejemplo para contratar más horas de difusión educativa en las radios y televisoras locales. Se ve limitado en exigir a las operadoras de servicio de internet mejoras en cuanto a capacidad y calidad del servicio. Ante la visibilización y notoriedad de esta precarización, la población de las "provincias" por su parte, reacciona de modo natural, solicitando a sus autoridades que exijan al gobierno central resuelva esta desatención histórica. Esta crisis sanitaria debiera visibilizar la necesidad de pensar la educación como un bien común y no solo como un mecanismo que perpetúe las desigualdades; en palabras de Boaventura de Sousa (2020) la crisis puede viabilizar un pensar el futuro hoy y en conjunto.

Desde nuestro medio venimos advirtiendo los riesgos de continuar la lógica colonial del poder basada en un centro desbordado por la historia y por las demandas de desarrollo de sus provincias. El sistema educativo no debería seguir siendo responsabilidad única del elefantiásico MINEDU. Ahí están las experiencias de los hacedores de cultura, entre los que se encuentran muchos docentes (Yangali 2019), que pese a no contar con los onerosos presupuestos con lo que se cuenta en la capital, vienen copando las tardes y noches culturales a través de cuenta cuentos, recitales, etc. Experiencias que no son remuneradas.

La administración de la investigación peruana, institucionalizada en el Concytec, sigue la misma lógica que la de los sistemas de salud, educación y cultura: se hace desde el centro y por lo general para el centro, con un añadido que raya con lo espurio, favorece la investigación desarrollada por instituciones privadas. 
El volumen poblacional e institucional (téngase en cuenta que no existe oficialmente ningún Ministerio o institución nacional que tenga su sede en otra región que no sea Lima o aledaña a ella) sería el insumo para justificar el centralismo. No obstante, no se trata de justificar esta perversa y discriminatoria lógica. Se trata de confrontarla y desarticularla, en una investigación más amplia hablábamos de este derrotero para la educación peruana (Yangali 2017).

Como se puede observar al hablar del avance anual del Perú en el ranking global de universidades (De-Moya 2020), la apuesta por el Minedu y por Concytec es clara: unas cuantas universidades capitalinas. No se aprende de los países que nos circundan. Brasil en primer lugar; luego, Colombia y últimamente Ecuador y Chile tienen universidades públicas y privadas no capitalinas que paulatinamente van posicionándose en lugares significativos en dicho Ranking. Su apuesta por descentrar la gestión de la investigación es meritoria.

Si bien la crisis educativa que se viene suscitando como daño colateral de la pandemia puede entenderse y afrontarse globalmente (Didriksson 2020) no debemos desatender sus raíces más añejas (calificados como viejos problemas por Gallardo 2000) y coloniales que no hacen más que decantar un vino ya rancio y tóxico. Nuestra exigencia implica que el Estado no crea en el retorno a la presencialidad como solución a la crisis sino en el que vele por asegurar la calidad dentro de esta misma; esto es en la educación virtual, y para ello le urgimos a pensar seriamente la descentralización del sistema.

Jorge Yangali

Director

\section{Referencias Bibliográficas.}

Congreso de la República (2014). Ley 30220, Ley Universitaria. https://www.sunedu.gob.pe/wpcontent/ uploads/2017/04/Ley-universitaria-30220.pdf

De Sousa, B. (2020). La cruel pedagogía del virus. Ciudad Autónoma de Buenos Aires: CLACSO. Libro digital.

De-Moya-Anegón, F. y otros (2020). Ranking iberoamericano de instituciones de educación superior 2020 (SIR Iber). Granada: Ediciones Profesionales de la Información. ISBN: 978841202393 o https://doi. org/10.3145/sir-iber-2020

Didriksson T., Axel (2020). Ante la pandemia, evitar reproducir la desigualdad social y educativa. En IISUE, Educación y pandemia. Una visión académica. México: UNAM. 154-163. http://www.iisue.unam.iisue/ covid/educacion-y-pandemia

El Peruano (2020). Decreto Legislativo No 1496. En Normas Legales de El peruano. 10 de mayo de 2020. https://busquedas.elperuano.pe/normaslegales/decreto-legislativo-que-establece-disposiciones-enmateria-d-decreto-legislativo-n-1496-1866211-3/

Gallardo Gutiérrez, Ana Laura (2000). Educación indígena en tiempos de COVID-19: viejos problemas, nuevos problemas. En IISUE, Educación y pandemia. Una visión académica. México: UNAM. 164-169.

Minedu (2020). Aprendo en casa. https://aprendoencasa.pe/\#/

Plá, Sebastián. (2017). Calidad educativa: historia de una política para la desigualdad. México: IISUE-UNAM.

Vargas, J. L. Y. (2017). Derroteros de la educación peruana en el XXI: interculturalizar, decolonizar y subvertir. Ensaio: Avaliação e Políticas Públicas em Educação, 25(97), 918-942. Epub February 06, 2017.https://doi. org/10.1590/s0104-40362017002500988

Yangali, J. (2019). Condiciones laborales de los artistas visuales y teatrales en Junín. Huancayo: UNCP. Inédito. 